\title{
Protesting “For Conscience’ Sake”: \\ Resistance to Civil Defense (CD) at Drew University, 1960 - 1962
}

\section{By Daniel J. Willever}

\section{DOI: http://dx.doi.org/10.14713/njs.v5i1.192}

In the midst of growing resistance to civil defense planning during the early 1960s, a series of protests occurred at Drew University. Students planned and participated in directaction civil disobedience against Operation Alert (OPAL) shelter drills on the campus in 1960 and 1961. This paper explores the legal and social consequences of those protests, contextualizing the student activism within the national anti-nuclear movement. Sources such as media coverage, organizational and personal correspondence, oral history interviews with participants, and court records are synthesized into an analysis of the student-activists' beliefs, plans, goals, and achievements. This paper argues that the protests are representative of a larger shift in the antinuclear movement. Despite the fact that the Drew protests garnered little public attention beyond New Jersey, they demonstrate a new phase of the Cold War, in which the average American felt empowered to take a stand against the once all-powerful nuclear state. The thirteen students who protested in 1960 or 1961 were motivated by their personal convictions and inspired by contemporary resistance movements. They were both empowered by and supportive of a cultural shift against the assumption that preparation for nuclear war was a patriotic duty that every American must embrace.

An air raid siren blasted across the campus of Drew University on May 3, 1960, echoing between old stone and brick buildings of the small liberal arts college, graduate school, and Methodist theological seminary. While most of the approximately 1,200 member campus population took shelter in accordance with New Jersey state law, six students committed an 
intentional act of civil disobedience by refusing to participate in the annual Operation Alert (OPAL) exercise. Seminarians Kenneth Williams, Louis Rowley, and Gary Klempnauer; graduate students Theodore Olson and Robert Goff; and college senior Gerow Reece gathered in front of the Student Union building for the duration of the drill. Olson, the de facto leader, held a sign that quoted then Governor of New Jersey, Robert Meyner: "CD shelter program is a cruel deception."1 Recounting the events of that day, Robert Goff recalled that "We didn't know what kind of attention this was going to get. It seemed like such a non-event for me [at the time]." His recollection is that no official approached or warned them, no one attempted to usher them inside. He wondered if anyone (students, university administrators, civil defense officials, or law enforcement) had even noticed them. ${ }^{2}$

It became evident within a few days that their civil disobedience was noted and would not be tolerated. This six were arrested and charged with refusing to obey or cooperate with the lawful orders of an air raid warden. ${ }^{3}$ Controversy surrounding the legal proceedings against them and the treatment they received by local press lasted well into summer break. Drew University Dean Allen L. Weatherby described the post hoc courtroom drama that unfolded as a "Roman Circus" that lasted nearly a month. Even after local magistrate Judge John C. Howe handed down sentences on June 2, the issue was far from over. ${ }^{4}$ Despite initiative on the part of University administrators to prevent another incident, resistance to the annual Operation Alert drill was repeated one year later despite their stern warnings. On April 28, 1961, a rally attended

\footnotetext{
1 "College Capers at New High," Madison Eagle, May 12, 1960; Author interview with Robert A. Goff, conducted by phone, March 6, 2019. Digital audio recording available upon request. Goff's placard echoed the Governor of New York, Nelson Rockefeller, "Civil Defense Is a Billion Dollar Boondoggle" Robert A. Goff, email to the author, March 5, 2019.

${ }^{2}$ Interview with Robert A. Goff, March 16, 2019.

${ }^{3}$ Complaint - Warrant, State of New Jersey vs. Theodore Olson, May 5, 1960, located in the Esther Frankel Papers [DG 097], Swarthmore College Peace Collection.

4 "Drew Students Call Magistrate 'Jackass;'; Howe Hands Ringleader Top Sentence; Four Refuse to Speak on Previous Record,” Madison Eagle, June 9, 1960.
} 
by an estimated 70 students preceded the siren blasts, and seven students refused to take shelter. ${ }^{5}$ For many years, policy makers had been concerned about public apathy and resistance towards civil defense (CD) planning. Even on a small, wooded campus in suburban New Jersey, the fact that opposition to civil defense preparation was growing could not be overlooked.

Unlike an air raid drill, this story does not start and stop with siren blasts in May 1960 or April 1961. Just as the narrative of these two protests cannot be fully understood in isolation from one another, they also cannot be properly analyzed in a vacuum. They occurred as a part of something temporally, geographically, and socially bigger. Rising discontent with civil defense programs was evident throughout the late 1950s and early 1960s. Resistance against Operation Alert drills throughout New York City and its surrounding metropolitan area, including college campuses, was present leading up to and including 1960 and $1961 .^{6}$ This paper will utilize the Drew University protests as a case study to explore resistance to civil defense preparation in the United States. By analyzing this microcosm of protest, the author hopes to answer a number of questions about the larger social movement in opposition to civil defense planning. What were the motivations of the protesters? To what extent did they subscribe to a larger movement for change? How did compliant Americans perceive of this rogue minority, those bold enough to take action in violation of a law that was intended to promote public safety? To what extent did such acts of civil disobedience cause a shift in public consciousness regarding the shelter drills being imposed on the public?

This author is not the first to explore such questions. The historiography of US civil defense is not a broad one, but several works have been produced in recent years that offer quality analysis and insights into the activism against nuclear war and, therefore, making

\footnotetext{
5 “Seven Sit Out During CD Alert," The Madison Eagle, May 4, 1961.

${ }^{6}$ For more information, see Dee Garrison, Bracing for Armageddon: Why Civil Defense Never Worked (New York: Oxford University Press, 2006): chapters 2 and 3.
} 
preparations to survive it. Guy Oakes, Tracy C. Davis, and Andrew D. Grossman are three scholars that have produced quality studies of the political, operational, and social aspects of Cold War civil defense programs; however, they largely ignore resistance movements that developed in opposition to this civilian mobilization. ${ }^{7}$ There are two well-researched works that supplement this deficit and have helped to inform the author of this study. Historian Lawrence S. Wittner's Confronting the Bomb: A Short History of the World Nuclear Disarmament Movement is an abbreviation of his comprehensive and essential trilogy of the global anti-nuclear movement. Wittner's work dissects the actions and achievements of a global anti-nuclear campaign during the Cold War. He argues that, very early in the Atomic Age, policy makers in the US and elsewhere were concerned about public resistance. Hence, the degree to which antinuclear activism (which Wittner refers to as "the biggest mass movement in modern history") worked to shape public policy is greater than was previously considered. ${ }^{8}$ Particularly in western democracies, policy makers were forced to contend with a small but outspoken group of activists that challenged the acceptability of a nuclear world. Even in the setting of a nuclear arms race, leaders were pushed to remain committed, at least rhetorically, to the pursuit of policies such as arms control, non-proliferation, testing bans, and disarmament. ${ }^{9}$ In contrast with what will be discussed in this paper, Wittner's book is a macro-view of a global movement and the public policy response that it catalyzed. It includes sporadic close-ups of activism, but as a condensed volume does not provide extensive detail. ${ }^{10}$

\footnotetext{
${ }^{7}$ See Tracy C. Davis, Stages of Emergency: Cold War Nuclear civil defense (Durham, NC: Duke University Press, 2007). Andrew D. Grossman, Neither Dead nor Red: Civilian Defense and American Political Development During the Early Cold War (New York: Routledge, 2001). Guy Oakes, The Imaginary War: civil defense and American Cold War Culture (New York: Oxford University Press, 1994).

${ }^{8}$ Lawrence S. Wittner, Confronting the Bomb: A Short History of the World Nuclear Disarmament Movement (Stanford, CA: Stanford University Press, 2009): 221.

${ }^{9}$ Ibid., 29.

${ }^{10}$ Ibid., 92. The protests against civil defense drills in the 1950s and 60s, for example, garner only about half a page in Wittner's condensed volume. For greater detail on events surrounding this study, see Wittner, The Struggle
} 
Dee Garrison's Bracing for Armageddon: Why Civil Defense Never Worked is a study of how the United States government attempted to indoctrinate the public and justify its nuclear weapon policies. Garrison describes civil defense measures as "one of the earliest, although almost wholly unsuccessful, government attempts to respond to the organized absurdities and horrors of the nuclear crisis."11 US political leadership viewed this as necessary because it was the only way they could convince the public to accept that nuclear deterrence (via Mutual Assured Destruction) was feasible. In short, US civil defense policy was aimed at "assuring an indefensible public that a proper... system would allow a meaningful number of citizens and the basic social structure to survive a nuclear strike without intolerable damage." 12 Why did this policy of assurance fail? One factor is that, rather than preparing the public for nuclear war, civil defense exercises like Operation Alert became an annual reminder of how futile such planning was. The drills provided pacifists and other nuclear skeptics with a high-profile public venue in which to protest, make a mockery of civil defense, and thereby more effectively diffuse their previously overlooked arguments to the general public. ${ }^{13}$ Much like Wittner's book, Bracing for Armageddon extends well beyond the Operation Alert protests of 1960 and 1961, though it focuses exclusively on US civil defense efforts. This narrower lens enabled Garrison to incorporate primary research and deeper analysis of a variety of different antinuclear activists and organizations that are glossed over by Wittner, including helpful analysis of Operation Alert protests in the New York City area. ${ }^{14}$

Against the Bomb, Volume Two: Resisting the Bomb: A History of the World Nuclear Disarmament Movement, 1954 - 1970 (Stanford, CA: Stanford University Press, 1997).

${ }^{11}$ Garrison, Bracing for Armageddon, 4.

${ }^{12}$ Garrison, Bracing for Armageddon, 4 - 5.

${ }^{13}$ Ibid., 113 - 114. Garrison says that Operation Alert enabled civil defense to be framed as a moral, rather than a political issue: "It served as a single cause that thousands could support for a day, with no political tests required for participation."

${ }^{14}$ Both Wittner and Garrison elaborate thoroughly on the work of pacifist organizations that will be mentioned peripherally in this paper: the Student Peace Union, Women's International League for Peace and Freedom, the War 
These scholars draw their conclusions from protests orchestrated by experienced (and often well-known) pacifists, supported by the resources of large organizations with fundraising capabilities and media operations of their own. Comparatively, grassroots activism that sprang up on college campuses in conjunction with larger "official" civil defense protests has received only peripheral attention in the historiography. ${ }^{15}$ This can largely be attributed to a disparity in available source material, most of which speaks to the beliefs, goals, efforts, and outcomes of veteran activists organizing the official protests. The tendency of scholars to focus their research on the leaders of civil defense resistance (rather than on those inspired by their leadership) is certainly a factor to be considered as well. This paper, therefore, will synthesize research of the grassroots protests at Drew with existing historiographical interpretations to develop insights about the public shift against civil defense. This will begin with an examination of the cultural milieu of civil defense in the late 1950s and early 1960s. It will subsequently offer an analysis of the protesters, to determine what factors inspired their activism, as well as how they viewed their actions vis-à-vis the larger movement unfolding beyond campus. The paper will conclude with an investigation into how the two protests were organized, executed, and the response they elicited from college administration, law enforcement, local community members, and the press.

The protests at Drew University were small, and occurred in conjunction with many significantly larger resistance gatherings. They garnered little public attention beyond the borough of Madison, N.J. Even some of the participants viewed their protest as insignificant. ${ }^{16}$ Available sources (such as letters, media coverage, university reports and memoranda, court

Resisters League, and National Committee for a Sane Nuclear Policy. See Wittner, Confronting the Bomb, or Garrison, Bracing for Armageddon.

${ }^{15}$ By "official protests," this author means those organized by pacifist organizations and their respective veteran activists. For example, the Operation Alert protests that took place at City Hall Park in Manhattan, New York City, between 1955 and 1961.

${ }^{16}$ Author interview with Gerow Reece, conducted by phone, March 1, 2019. Digital audio recording available upon request. Interview with Robert A. Goff. 
documents, and oral histories) suggest that significance can be found in this microcosm of student activism. The argument put forth here is that these two protests are representative of a larger shift in the antinuclear movement. They demonstrate a new phase of the Cold War, in which the average American (in contrast with veteran activists and their supporting organizations) felt empowered to take a stand against the all-powerful nuclear state. The thirteen students who protested in 1960 or 1961 were motivated by conscience and inspired by contemporary resistance movements. They were both empowered by and supportive of a cultural shift against the assumption that preparation for nuclear war was a patriotic duty that every American must embrace. This paper suggests that the historical significance of these protests is not exclusive to the activism itself. The protests catalyzed reactions in the press, among community members, and from other activists, that are informative yet underappreciated in existing scholarship. This paper will explore the ripple effects of resistance that inspired some, angered others, and sparked public deliberation of vital democratic values: the utility of dissent, the power of conformity, the role of the press, and the consequences of acting in accordance with one's own conscience.

With the passage of the Civil Defense Act in 1950, the federal government launched a reorganization of its efforts to mobilize the American public in response to a domestic nuclear bomb attack. This mobilization required cooperation between the state (public structures at every level) and private entities: major research universities, corporations, and most importantly, individuals and families. ${ }^{17}$ The Federal Civil Defense Administration (FCDA) launched numerous educational programs and public safety initiatives to prepare the American public for a worst case scenario. Operation Alert, which Garrison describes as a "giant annual sociodrama,"

\footnotetext{
${ }^{17}$ Andrew D. Grossman, Neither Dead nor Red, 73 - 75. For analysis of the family and civil defense, see Laura McEnaney, civil defense Begins at Home: Militarization Meets Everyday Life in the Fifties (Princeton, NJ: Princeton University Press, 2000).
} 
was initiated by the FCDA in an effort to "demonstrate government mastery of... crisis through the flawless operation of civil defense" and present a facade of order and control in the midst of widespread nuclear catastrophe. Following a 1954 "dress rehearsal" that did not require public participation, the mandatory shelter drills were carried out from 1955 to 1961 in more than sixty cities and their respective metropolitan areas. The drills were signaled by sirens and typically lasted for about fifteen minutes, as police, air raid wardens, and other civil defense officials attempted to enforce the shelter requirements. ${ }^{18}$ The publicity campaign of government-issued propaganda (primarily films, images, and statistics) that accompanied some of the earlier drills was designed to sell Americans on the idea that they could emerge from a widespread nuclear attack mentally and physically unscathed if they just sought appropriate shelter. For most Americans, who for nearly a decade had been warned of the destructive capabilities of nuclear weapons and were living amidst of growing concerns about radiation fallout, the narrative being promoted by FCDA propaganda was preposterous. ${ }^{19}$

Garrison credits these national air raid drills with catalyzing rapid expansion in the antinuclear movement: "The existence of Operation Alert fired the peace movement into action..." by providing antinuclear advocates with an ideal opportunity to demonstrate the preposterous nature of civil defense (and thereby the insanity of US nuclear deterrence policy) to a broad swath of the American public. ${ }^{20}$ In 1955, the earliest protests were isolated to major cities such as New York City, Boston, Philadelphia, and Chicago. In Manhattan, a couple dozen dissenters gathered on benches at City Hall Park, where they brandished signs and distributed pamphlets. They consisted of men and women, ranging in age from early twenties to seventy

\footnotetext{
${ }^{18}$ While the public was aware of the date on which the drill would be conducted, the exact time was often concealed. ${ }^{19}$ Garrison, Bracing for Armageddon, 70 - 71. Images of government officials, including President Dwight Eisenhower, nestled safely in a secret, isolated location as potentially millions of Americans were "obliterated" did little to allay public concerns.

${ }^{20}$ Ibid., 56.
} 
years of age, and were affiliated with various pacifist organizations such as the Catholic Workers, Quakers, and the War Resisters League. That year twenty-seven protesters were arrested and all but two of them were tried over subsequent months.

Both Garrison and Wittner describe a flourishing of the antinuclear movement, nationally and internationally, between the years 1955 and 1962. As concern about nuclear testing and the arms race was on the rise, resistance to Operation Alert drills also increased. By 1960, the air raid drills were met with highly organized and expansive protests, and pacifist organizers welcomed the broader public into the resistance movement. ${ }^{21}$ At City Hall Park, Manhattan on May 3, 1960, nearly 1,000 protesters gathered; many were women accompanied by their children. About 500 individuals remained in the park, at risk of arrest, during the shelter period. Some curious non-resisters emerged from shelters to observe what would happen. ${ }^{22}$ Wittner estimates that the City Hall Park protesters numbered some 2,500 the following year; they were joined by demonstrations in New Jersey, Connecticut, Pennsylvania, Massachusetts, Illinois, and Minnesota. ${ }^{23}$ Simultaneous protests occurred at high schools and college campuses in and around the city, including Cornell, Princeton, Rutgers, the City College of New York, Drew, and 500 students at Columbia who sat on the library steps for the duration of the drill. It was evident that resistance to civil defense had reached a tipping point. ${ }^{24}$ Mary Sharmat, a leader of the civil defense Protest Committee that was responsible for organizing the protest in downtown Manhattan, noted that: "Civil defense at last became an issue” after OPAL '60. "It was no longer ignored as an unimportant nothing to put up with because it's easier..." New York Post columnist Murray Kempton seemed to concur: "We seem to be approaching a condition of sanity where

\footnotetext{
${ }^{21}$ Wittner, Confronting the Bomb, 92; Garrison, 96 - 97.

${ }^{22}$ Garrison, 99 - 100.

${ }^{23}$ Wittner, 92; Tracy C. Davis, Stages of Emergency, 54.

${ }^{24}$ Garrison, 113.
} 
with a year or so there'll be more people defying than complying with the civil defense drill." 25 Hyperbole, perhaps, but it was becoming more evident that large swaths of the public were disregarding or combatting government efforts to make civil defense preparation an ordinary component of American life.

Theodore Olson, described as "an activist in temperament as well as ideology," was busy in the days preceding OPAL ' 60 . Olson spoke with peers about protesting the forthcoming drill, and encouraged them to join him. As a graduate student, Olson would have been relatively isolated from the majority of the student body undergraduates at Brothers College. ${ }^{26}$ This may account for the fact that most of the protesters who joined him on May 3 were seminarians from the theological school, with the exception of Goff and one undergraduate senior, Gerow Reece. Goff considered himself a friend of the protest organizer, and remembers that Olson was inspired by direct-action, non-violent protest that had become an integral component of the ongoing Civil Rights Movement. Olson, a minister, had also done a lot of work with the American Friends Service Committee (Quakers) and was a self-proclaimed pacifist. It was through conversations with his friend that Goff developed his own convictions about civil defense. He had read books on nuclear war, such as John Hersey's Hiroshima, but considered himself to be in the political mainstream. As a doctoral student of Theological Studies, he was exposed to a lot of philosophy but it was Olson's words that enabled him to fully consider the "futility" of civil defense and the necessity of the protest: "I didn't have to study it to know that there was no civil defense. The whole... [program] seemed to me to be sponsoring the illusion that it is possible to be safe in a nuclear war."27

\footnotetext{
${ }^{25}$ Ibid., 101.

${ }^{26}$ Author interview with Robert A. Goff, March 6, 2019. According to Goff, Theodore Olson was already an active minister at a local church while completing his graduate studies at Drew.

${ }^{27}$ Author interview with Goff, March 6, 2019.
} 
Not much is known about the other individuals who resisted OPAL '60. Gerow Reece was the only undergraduate, a Quaker, and according to his yearbook a believer in "quiet nonconformity." 28 Kenneth Williams, Louis Rowley, and Gary Klempnauer were all seminarians at the theological school and likely had direct contact with Pastor Olson. ${ }^{29}$ Considering all that is known about this cohort, a simple conclusion about their reason for protesting the air raid drill is that they shared skepticism of civil defense, and aversion to the inevitability of nuclear war. Their educational pursuits exposed them to religious and philosophical teachings that decried violence, thereby reinforcing pacifist tendencies. Yet, as young adults, most had no previous experience in civil disobedience. There are two questions to consider regarding this fact: living in such close proximity to New York City, why had they not participated in previous OPAL protests, which had been ongoing since 1955 ? Why not travel into the city to participate in the activism there, instead of protesting on campus? The answer is multifaceted. First, the early OPAL protests were small, somewhat exclusive to veteran activists, and dominated by women; 1960 was the first year in which the protest expanded beyond a core group of metropolitan pacifists. ${ }^{30}$ Secondly, personal time constraints must be considered. Goff indicated that he was aware of the protests, and had friends at New York City colleges who had first-hand exposure to the resistance movement. His study schedule was one additional obstacle, so "the fact that there was one on campus that year was quite convenient." 31 Third, the campus offered a relatively sheltered environment in which to protest. The likelihood of arrest and having one's name or photo appear in the paper was low compared with the high-profile, high risk environment across the Hudson River.

\footnotetext{
${ }^{28}$ Author interview with Gerow Reece, March 1, 2019; 1960 Drew University undergraduate yearbook, page 45, accessed at the Drew University Archives.

${ }^{29}$ Author interview with Robert A. Goff. According to Goff, the ringleader had been trying to get more seminarians to participate in the protest just prior to the air raid drill.

${ }^{30}$ Garrison, Bracing for Armageddon, 92 - 96.

${ }^{31}$ Author interview with Robert A. Goff.
} 
The juxtaposition of the first Drew CD protest with that of the following year offers a stark contrast. First, the seven students who protested in 1961 were an entirely new cast of characters, despite the fact that many of the original protesters were still on campus. The second iteration consisted mostly of undergraduate students, four of whom were freshman and three of whom were women: Janet Sykes, Nancy Frith, Jo Ann Mongiore and Robert Fluck were all members of the Brothers College class of 1964. They were joined by two older undergraduate males, sophomore Richard Fredericks and senior Neal Mosher; and one seminarian, Lois Congdon. ${ }^{32}$ It is difficult to determine why there is no redundancy between 1960 and 1961 in terms of who protested. Having been a senior in 1960, Gerow Reece obviously was no longer on campus, and many of the seminarians may have completed their studies in the interim, or had other responsibilities at the time of the drill. Both Robert Goff and Theodore Olson remained on campus one year after the initial protest, but neither participated in direct action resistance. Available sources are clear that Olson was still active on campus during the 1960 - 1961 academic year, including in opposition to civil defense behind the scenes. ${ }^{33}$ Together with Ted Olson, seminarians Lois Congdon and Martin Deppe, and undergraduate Peter Mosher, worked to establish a new campus organization called ARROW: Associated Realists Resisting Organization for War. ${ }^{34}$

The origins of ARROW are not specified in any source, but circumstantial evidence suggests how it came to be. In December, 1960, the Drew Council on Nuclear Warfare met for

\footnotetext{
32 "Seven Sit Out During CD Alert," The Madison Eagle, May 4, 1961.

${ }^{33}$ ARROW flyers, accessed March 18, 2019 at the Drew University Archives, Cabinet 1, Drawer 2, Folder 10. When asked about his lack of involvement with the 1961 protest in the interview, Goff gave a personal answer: his father, who was stationed high in the command structure of the US Coast Guard, had written him a letter following the legal troubles that succeeded the 1960 protest. Although he expressed no opposition to his son's philosophy or opposition to civil defense, he was concerned that further disobedience on Robert's part might result in a record that would hinder his future endeavors.

${ }^{34}$ ARROW flyers, Drew University Archives. Peter Mosher and Neal Mosher are two different individuals, both members of the class of 1961. It does not appear they were related.
} 
the first time (and possibly the last). The group was a "loosely knit association" with the intention of promoting "informed discussion of the implications of warfare in the nuclear era." The organization was "informal" but led by a student named David Faison. At the premier meeting of the Council, Peter Mosher announced the interest of some students in forming a campus chapter of the anti-militarist Student Peace Union. In response, "Faison stressed that the council would not associate itself with any organization" and was open to all members of the campus community, pacifist and non-pacifist alike. ${ }^{35}$ At the end of March, 1961, a group of Drew students joined an anti-nuke "Easter March for Peace" in Plainfield, organized by the New Jersey division of SANE (an antinuclear group). ${ }^{36}$ A month later, a representative of the War Resisters League came to campus to speak on the topic of "Neither Run Nor Hide," a discussion of civil defense. David McReynolds attempted to motivate the students (members of ARROW, one can presume) into action by comparing the apathy of Americans towards civil defense with the Germans' unwillingness to resist Adolf Hitler's rise to power. ${ }^{37}$ The article on McReynolds visit was written by Neal Mosher and gave reasoning from the War Resisters League (WRL) representative for why the students should resist OPAL ' 61.

When several local newspapers ran articles announcing the planned student protest in the days preceding Operation Alert '61, Neal Mosher was identified as the spokesman for ARROW. In the Madison Eagle, a quote from Mosher outlined the protest components and described the resisters as those "convinced that the civil defense law is immoral and ambiguous." "38 The Morris Record of nearby Morristown published a longer quote: "The discipline of this protest will be one of non-violence following the examples of Gandhi, Thoreau and the 'sit-inners' in the

\footnotetext{
35 “Council Delves into Nuclear Pros-Cons," Drew Acorn, December 5, 1960.

36 “"Peace Marchers' Leave Plainfield,” The Courier-News (Bridgewater, NJ), March 29, 1961.

37 Neal Mosher, "McReynolds Speaks Against civil defense," Drew Acorn, April 24, 1961.

38 “Drew Students Plan 'Sit-Out' During CD Drill," The Madison Eagle, April 27, 1961.
} 
South." 39 One article went on to note that the student actions on Drew's campus were "autonomous" from the planned protests elsewhere, but also described it as part of a "nationwide movement" against civil defense. Taking all this into account, it is proper to conclude that the student activists were inspired by historic and contemporary protests, and influenced by organizations active in the national movement against civil defense. Yet, they opted to remain unaffiliated from groups such as SANE, the Student Peace Union, and the WRL. ${ }^{40}$ Certainly, this allowed them greater flexibility to deliberate the best course of action for themselves and act accordingly. It also may have been a consequence of a theological presence within the student movement, as the leaders of ARROW chose to publicly invoke "Christian concern" in their fight against civil defense planning. ${ }^{41}$

If the 1960 protest should be considered spontaneous in nature, the second protest was just the opposite, having been planned and publicly announced by ARROW's leadership. In an effort to build support for a larger protest in 1961, ARROW distributed two flyers to the Drew student-body, one of which advertised the group as a "coordinating committee set up specifically to deal with the April 28 exercises." Specifically, “activities [to be] carried out under a discipline of non-violence which includes a respect for the structure of law itself most deeply when we obliged not to comply with an individual law, for conscience' sake."42 The two leaflets circulated on campus were quite different. One, entitled "A Resolution Concerning civil defense," was a direct copy of a polemical resolution approved by The General Board of Christian Social Concerns of the Methodist Church. This document was not overtly religious, speaking vaguely

\footnotetext{
39 “To Protest CD Drills In Sit-Out," Morris Record (Morristown, NJ), April 22, 1961.

40 Garrison, Bracing for Armageddon, 89, 113. High school and college chapters of SANE were active as early as 1957, when the organization boasted over 25,000 members across the country, and it encouraged resistance to civil defense drills in 1960 and 1961.

${ }^{41}$ ARROW, "A Statement Concerning civil defense," Drew University Archives, Cabinet 1, Drawer 2, Folder 10. ${ }^{42}$ ARROW, "IF YOU WANT TO TAKE PART IN THE CAMPUS PROTEST AGAINST CIVIL DEFENSE...," Drew University Archives, Cabinet 1, Drawer 2, Folder 10.
} 
of "Christian concern for the welfare and peace of all mankind," and offering four secular warnings against civil defense preparations. One proclaimed, for example: "Some experts believe that a full-scale Civilian Defense program might indicate to the enemy a readiness to initiate war and therefore trigger an enemy attack." It summarily proclaimed: "The only sure defense is a world at peace." 43 In providing this to the student body, ARROW may have been attempting to appeal to the Christian background that many Drew students shared (43\% of the undergraduate classes were self-described Methodists in 1961, and a healthy majority subscribed to Christian denominations). ${ }^{44}$ Religious affiliation aside, the resolution was probably distributed out of a matter of convenience and pragmatism. As members of the theological school, Deppe and Congdon would have had access to this type of institutional declaration, and the official origins of the document would have given legitimacy to their own beliefs. Although their "Christian conscience" helped to shape their worldview and appeal to others, ARROW was not a religious organization, and those students opposed to civil defense were instructed more so by political and philosophical views than by any religious doctrine or belief. ${ }^{45}$ That the students elected to name their organization "Associated Realists" as opposed to "Associated Christians" should indicate more than the desire for a memorable acronym on their part. The chosen name expresses a pragmatism otherwise hidden by the idealist underpinnings of the resistance movement.

The second flyer was a directive to the Drew student-body. It offered "First Steps" that one might take: "Work out your own relation to the issue..." of civil defense; "Discuss these issues with your friends and family...;" and "Decide the level of action in which you want to

\footnotetext{
${ }^{43}$ ARROW, “A Statement Concerning Civil Defense."

44 "Summary of Students with Methodist Preference and Religion Concentrations, 1936 - 1964," Drew University College of Liberal Arts, located at Drew University Archives, College of Liberal Arts Records, Box 61, Folder "Religious Preference of Students, 1930s - 50s - '64."

45 “State v. Congdon, 76 NJ Super. 493 (1962),” Justia, accessed 4/20/2019, https://law.justia.com/cases/newjersey/appellate-division-published/1962/76-n-j-super-493-0.html. Cited content contained on page 509.
} 
participate on April 28." It offered options for what those actions might be, such as participating in the open rally before the sirens, distributing flyers in the shelter areas, or disobeying the sirens by remaining outside during the shelter period. Finally, it provided information on the legal situation in which those who resisted might find themselves. This also included a promise that, if arrests occurred, "appeal [would] be made and followed through, since... legal counsel suggests that there is a serious question as to whether in fact the law can be made to apply to our situation." 46 The Morris Record account of ARROW's plans took this even further: "...to bring the law to a test in the courts on the basis of its ambiguity." 47 Their desire for the chance to challenge the legitimacy of civil defense arrests in court was a bold new step, considering the protesters of the year before didn't even think there was a significant chance of arrest.

Both Gerow Reece and Robert Goff acknowledged that they didn't seriously consider the possibility of arrest when deciding to protest in 1960. Goff said, "If someone had asked me ['Do you think you'll be arrested?'] before, or as we convened... I would have said no..." because of "the fact that there had been no one there, no one said anything. The administration had not sent out a warning." ${ }^{48}$ Documentary evidence contradicts Goff's recollection, however. According to a May 27 Morris Record article, the deputy director of campus civil defense, Charles F. Nelson, claimed that "he asked the students to step in a shelter and warned them that... they were subject to arrest if they refused to take shelter." ${ }^{49}$ Whether or not arrest was expected, it wasn't until May 5 that Goff was tipped off by a staff member of his impending detainment. ${ }^{50}$ A borough

\footnotetext{
46. ARROW, "IF YOU WANT TO TAKE PART IN THE CAMPUS PROTEST AGAINST CIVIL DEFENSE..."

47 “To Protest CD Drills In Sit-Out," Morris Record.

${ }^{48}$ Author interview with Robert A. Goff.

49 “Students Seek Dismissal of CD Violation Charges," Morris Record (Morristown, NJ), May 27, 1960.

${ }^{50}$ Author interview with Robert A. Goff; Complaint - Warrant, State of New Jersey vs. Theodore Olson, May 5 , 1960. The official complainant listed on the complaint against Theodore Olson filed in the Municipal Court of Madison, NJ was a man named Charles Nelson. According to the Morris Record, he was the deputy director of civil defense on campus and filed the complaint. However, the May 12, 1960 edition of the Madison Eagle names Ralph Smith, Drew University director of buildings and grounds as well civil defense security officer, as the individual
} 
vehicle was sent to collect the entire group on May 12; they were booked on misdemeanor charges, and scheduled for a municipal court appearance that evening. ${ }^{51}$ The group was held only briefly (maybe a few hours) at the local jail, individually in separate cells, and could not see one another but could communicate verbally. Two visitors from the Drew Theological School arrived during the holding period: Franz Hildebrandt and John Godsey. The former, a Lutheran Minister and prominent German theologian, "was very kind and pastoral" towards the incarcerated men and even had some books sent down from the University later in the day to help pass the time. Godsey, an expert on the work of theologian Dietrich Bonhoeffer, was younger and junior to Hildebrandt. Goff's recollection is that the two men, in showing up, "made it clear. . . that they were identifying us..." with historical resistance movements, such as those that Bonhoeffer (and Hildebrandt himself) had fought against Nazi rule in Germany before World War II. ${ }^{52}$ Even in the midst of their arrest and uncertain legal outlook, the protesters were comforted in the fact that they had allies on campus, especially men of such a reverential status from the perspective of student activists.

The first local media coverage of the event came on May 12, 1960, with the Madison Eagle article "College Capers at New High." This described the protest in the context of other, ongoing troubles between the student body and university administration. It also indicated the arrested men were scheduled to appear in the courtroom of local magistrate Judge John C. Howe that evening. The men were released after that hearing with a trial date of Thursday, May 19,

who filed charges. "College Capers at New High," Madison Eagle, May 12, 1960. Regardless of whether it was Nelson or Smith that filed the complaint, they were later criticized for not informing any members of the administration about the situation and "taking action into their own hands." Many felt that any disciplinary matters stemming from the protest could have been handled in-house. Les Banks, Letter to the Editor, Madison Eagle, May 19, 1960. Both Smith and Nelson were replaced during the next academic year. A document in the files of Professor Robert Bull dated October 11, 1960 indicates that he was appointed as one of the new campus coordinators during the following school year. Bernhard Anderson to Robert Bull, October 11, 1960, Drew University College Archives, Papers of Dr. Robert Bull Box.

${ }^{51}$ Complaint - Warrant, State of New Jersey vs. Theodore Olson, May 5, 1960.

${ }^{52}$ Author interview with Robert A. Goff. 
which was postponed by one week because their attorney, Esther Strum Frankel, was scheduled to argue before another court on that day. Frankel was herself a pacifist and activist member of the Women's International League for Peace and Freedom, a group active in CD resistance. She argued a number of civil rights and disorderly conduct cases stemming from protest throughout the 1950s, 60s, and 70s. ${ }^{53}$ When court convened on May 26, all of the students pleaded not guilty and Frankel argued before Judge Howe to have the complaint dismissed. She defended the students "on the grounds that there are no provisions in the State statute on civil defense that cover test drills." She provided statutory examples for the judge which "referred to threats, imminence of danger, and emergencies," and argued that there was no emergency on Drew's campus at the time of the OPAL drill. Howe was skeptical of the argument; if the law made no provisions for test raids, "we've been working many years for nothing." He also chastised the students "for their disobedience to the laws of the country and suggested they think about how they're going to teach their people to obey when they become ministers." Howe opted to delay the case again by one week, so as to better familiarize himself with the New Jersey statutes governing civil defense and get input from the local civil defense director, Robert S. Deasey. ${ }^{54}$ The stage was set for June 2 .

As the Spring 1960 legal proceedings played out, a different type of battle was being waged in the local press. The opening salvo came in the form of the opinion editorial "A Matter of Hospitality," published by the Madison Eagle on the day the protesters were arrested: "We are sorry that a few immature persons from Drew University need to go on trial tonight...It is quite obvious that the people concerned are looking for martyrdom and a certain notoriety." But the

53 “Esther Frankel Papers, 1948 - 1975," Swarthmore College Peace Collection, updated August 21, 2015, https://www.swarthmore.edu/library/peace/DG051-099/dg097Frankel.htm. It is not known how Frankel came to represent the protesters. Robert Goff considered the possibility that someone on the campus was familiar with her and reached out to ask her to take the case, as it was the perfect fit for her legal background and personal convictions.

54 “Students Seek Dismissal of CD Violation Charges," Morris Record, May 27, 1960. 
editors went beyond targeting the protesters; they proceeded to attack the student body as a whole for recent "items of friction" with the citizenry of Madison, including a protest of segregation outside of the downtown Madison Woolworths. To the Eagle, the arrest of these students signaled a new low in community-university relations: "a flat-handed slap to the... people of Madison who have given of their time for ten years or more in the hope that they might evolve some sort of protection... against nuclear damage." It even went so far as to subtly suggest that the borough should reconsider the university's tax-exempt status, and that the university should improve its screening of applicants to prevent future issues. ${ }^{55}$

The response was swift, as the next several issues of the Madison Eagle contained more than a dozen letters to the editor by the Drew student-body, faculty, and community members offering rebuttals to and denouncements of the editorial. "If you knew the persons who were involved in the slightest bit, you would know that 'martyrdom and notoriety' were certainly not the purpose of their protest" wrote student Les Banks in defense of the protesters. ${ }^{56}$ Some sought to turn the words of the editorial against the paper: "If the actions of the Drew students are to be most unjustifiably construed as a 'flat slap to the people of Madison' then [the Eagle has] certainly retaliated in the best eye-for-an-eye manner." ${ }^{57}$ In the next issue of May 26, community member John P. Snyder celebrated the non-conformity of Drew's student-activists: "I say it is important that these people be encouraged to take public stands to demonstrate beliefs which they sincerely feel are fundamental to our country's advancement as a moral democracy... These protesting students are not involved in panty raids and cheating; they are involved in fundamental issues of our society and...we need them." 58 In contrast with these comments, not

\footnotetext{
55 “A Matter of Hospitality," Madison Eagle, May 12, 1960.

${ }^{56}$ Les Banks, Letter to the Editor, Madison Eagle, May 19, 1960.

${ }^{57}$ Mary Jean Smith, Letter to the Editor, Madison Eagle, May 19, 1960.

${ }^{58}$ John P. Snyder, Letter to the Editor, Madison Eagle, May 26, 1960.
} 
one single letter supporting civil defense or criticizing the protest was published in the Madison Eagle during May and June, 1960.

The editorial board of the Drew Acorn used their own publication to jump into the fray. In a May 16 editorial entitled "Civil Defense vs. Civil Rights" the student editors lamented that "Three steady one-minute sirens on the afternoon of May 3 seem to have announced everything but a return to the 'all clear' status quo, as feelings, opinions, and accusations mount... Not only has peace been disturbed far beyond the extent of the original protest demonstration, but many of the approaches to the situation seem negative." The editors included several illuminating pieces of information. First, large swaths of the student body did not participate in the shelter drill, including many residents of Asbury Hall and undergraduates attending class in Brothers College at the time. There were also a number of students who "were excused from legal responsibility" by pleading ignorance. The Acorn also chose to defend Ralph Smith, the campus director of civil defense then under fire from the student body for filing the police report. The Acorn pointed out that, as a civil defense official, he had legal responsibilities that superseded his role as a university administrator. Finally, the editorial board responded to the Madison Eagle editorial with "unreserved scorn," and offered a point-by-point rebuttal to the community press attack on the university. ${ }^{59}$ To the credit of the student paper, it demonstrated a noteworthy level of maturity in the closing paragraph by dismissing the subsequent controversies as a distraction from the real issue:

As we see it, the basic question raised by the situation should have been... One of the relationship of individual rights to federal authority. This is not an easy relationship to determine, nor is it infrequently that it is brought to the fore, but it seems that this should, nevertheless, be the proper focus of our concern with this issue. ${ }^{60}$

\footnotetext{
${ }^{59}$ Editorial Board, “Civil Defense vs. Civil Rights,” Drew Acorn, May 16, 1960.

${ }^{60}$ Ibid.
} 
The reporting of the Madison Eagle offered more fodder for rebuke with its coverage of the June 2 court proceedings. A large crowd of supportive students and other members of the community packed the courtroom that evening, as Judge John Howe heard arguments and rendered his decision. The room was so full that some were seated on the windowsills, stood on top of garbage bins, and an overflow crowd waited in the hallway. Howe was repeatedly interrupted by demonstrating students and had to threaten eviction several times. The subsequent edition of the Madison Eagle featured a misleading banner headline that began "Drew Students Call Magistrate 'Jackass'." The article elaborated that an unnamed 22-year-old student was overheard referring to the judge in this way, but no source was cited. The "circus" atmosphere aside, the outcome was not good for the students. Esther Frankel attempted to have some of the accused students testify, to which Howe replied: "What is the use of having this person testify if he admits he is guilty? It is only a question of whether or not this law was disobeyed." ${ }^{61}$ Howe rejected all arguments made by the defense, stating that the law empowered civil defense officials to enforce shelter drills regardless of whether or not a real emergency existed. The sentences that Howe handed down reflected the degree to which each protester had cooperated in court, as four of the students had refused to answer some of his questions. Kenneth Williams and Gerow Reece received the smallest punishment: \$10 court costs and a suspended sentence. Robert Goff, Gary Klempnauer, and Louis Rowley received a \$10 fine plus court costs. As the "protest instigator," Theodore Olson was fined $\$ 50$ plus costs. Judge Howe took one last verbal shot at Olson before adjourning: "The testimony [indicates]... that you urged your fellow students to violate the law. If you don't want to pay the fine you can spend the time in jail." 62

\footnotetext{
61 “Drew Students Call Magistrate 'Jackass'; Howe Hands Ringleader Top Sentence; Four Refuse to Speak on Previous Record," Madison Eagle, June 9, 1960. Howe did, however, allow faculty member Dr. James a McClintock to testify as a character witness for the accused. ${ }^{62}$ Ibid.
} 
The coverage provided of the hearing by the Madison Eagle was once again the subject of rebuke, and letters addressing the issue were published throughout the month. Drew Professor Robert Friedrichs expressed shock at the banner headline chosen for the coverage. He accused the Eagle of journalistic malpractice for contorting the facts to make it seem as though one of the accused had insulted the judge. Friedrichs continued: "Nowhere in your reporting... has it been pointed out that all six of the defendants were young men acting in terms of their Christian conscience." While he acknowledged that his personal convictions towards civil defense differed from those of the students, he lambasted the paper's coverage as "a disservice to the University, the community..." and the press as a whole. ${ }^{63}$

Not everyone was dissatisfied with the legal and social outcome of the case, however. On June 6, 1960, Robert A. Goff wrote a letter to attorney Esther Frankel: "I am proud to have been associated with you... and I'm certain I speak for others when I say that your concern and skill won the respect and admiration of each of us and many others in the Drew community..." Enclosed with the letter was a postal money order in the amount of $\$ 130$, plus a personal check for $\$ 10$ (from Dr. Robert Friedrichs). "Although it is in excess of the amount you agree to accept," Goff acknowledged, "the many donations we received from Drew students and faculty members and from townspeople enable the six of us to offer you what we think you earned." 64 In their written support, personal demonstration at the courthouse, and financial contributions, many at Drew and in the borough of Madison rallied to defend the protesters in the face of perceived injustice.

The protest, resulting court case, and press coverage begotten of it were a headache for the Drew University administration, as exemplified in their desire to prevent a similar problem in

\footnotetext{
${ }^{63}$ Robert W. Friedrichs, Letter to the Editor, Madison Eagle, June 16, 1960.

${ }^{64}$ Robert A. Goff, letter to Esther Frankel, June 6, 1960, located in the Esther Frankel Papers [DG 097], Swarthmore College Peace Collection.
} 
1961. Ralph Smith and Charles Nelson were replaced as campus CD officials, perhaps because of their decision to press charges without first consulting with the administration. ${ }^{65}$ When it became known that Operation Alert 1961 would occur on April 28, and ARROW's activism made it clear that another protest was likely, Drew's President Robert Fisher Oxnam took action. On April 3, a "Statement of University Policy" was issued. While proclaiming Drew to be an institution founded on "the free and critical exchange of ideas, based on informed opinion and responsible concern for general welfare..." the statement was intended as a warning for all students considering a second protest. "Freedom of thought and freedom of conscience are possible, however, only within a structure of law and order... If a member of the University, on the basis of his conscience, is led to violate a law, he must be prepared to face up to the consequences of his actions." Oxnam reserved the right to take disciplinary measures in response to civil disobedience. ${ }^{66}$ The statement was published in the April 17 edition of the Drew Acorn. ${ }^{67}$ An editorial written by Dean Allen Weatherby also appeared in the student paper, advocating strongly against the planned protest. Weatherby outright dismissed any conflation between OPAL protests and disobedience within the ongoing Civil Rights Movement. He also argued that the protest would be viewed poorly by the community and the nation, resulting in detrimental effects to the university as a whole in matters reputation, fundraising, and recruitment: "It is a strange kind of non-violence which does violence to all members of a community of which one is a member." 68

\footnotetext{
${ }^{65}$ Drew University Memorandum from Vice President John L. Pepin, undated, Drew University Archives 1:2:10. "Reports Results in OPAL Exercise," Madison Eagle, November 3, 1960.

${ }^{66}$ Robert Fisher Oxnam, “A Statement of University Policy -- April 3, 1961,” Drew University Archives 1:2:10.

${ }^{67}$ Robert Fisher Oxnam, letter to the Members of the Board of Trustees, April 14, 1961, Drew University Archives 1:2:10. In this letter, Oxnam shared the statement and predicted that "there might be some student, faculty, or public reaction..." "Oxnam Issues Statement Of CD Policy," Drew Acorn, April 17, 1961.

${ }^{68}$ Dr. Allen Weatherby, "Dean Allen Weatherby Remarks on CD Protest, Drew Acorn, April 10, 1961.
} 
Whereas controversy and debate had swirled only after the unforeseen 1960 protest, anticipation of another incident and the administration's efforts to prevent it sparked antecedent deliberation at Drew. As early as April 10, the Drew Acorn ran an anonymous article blasting the purpose and effectiveness of civil defense: "The function of $\mathrm{CD}$ is primarily to persuade Americans that they can somehow handle and survive nuclear warfare. This is unjustifiable deceit." ${ }^{69}$ Additional opinions followed the publication of Weatherby's letter and Oxnam's statement. In direct response to Weatherby, Robert Goff thrashed the Dean's view that protesting civil defense was both a trivial act (when contrasted Civil Rights activism) and a powerful one that threatened the welfare of the university and all its students. ${ }^{70}$ The April 24 edition (the last before OPAL '61) devoted multiple pages to the controversy. One "S.M.C." wrote a celebration of dissent at universities and argued that, while the state may punish dissenters to Friday's alert, Drew should take no actions against them so long as no University statutes were violated..$^{71}$ The Methodist Student Movement chapter at Drew published a lengthy statement advocating that no action should be taken "against those participating in any civil disobedience according to the dictates of their own Christian conscience." ${ }^{72}$ David Faison (of the Drew Council on Nuclear Warfare) advocated that all members of the community, be they in favor or in opposition of civil defense, should act in accordance with their conscience during the forthcoming drill, and he lambasted Dean Weatherby: “To hell with Drew University and its precious public image... [Only] the most blind and shallow amongst us..." would place the reputation of a university above "a question involving millions of human lives." "73 Theodore Olson mounted a stirring defense of ARROW and its mission in an article adjacent to Faison's letter: "We take this action

\footnotetext{
69 "CD Plan Put to the "Test,"” Drew Acorn, April 10, 1961.

${ }^{70}$ Robert A. Goff, “Goff Responds to Weatherby,” Drew Acorn, April 17, 1961.

71. S.M.C., "The Right to Dissent," Drew Acorn, April 24, 1961.

72 "MSM Addresses University on Methodist Stand on Protest," Drew Acorn, April 24, 1961.

${ }^{73}$ David Faison, “Civil Defense Reviewed...” Drew Acorn, April 24, 1961.
} 
as a part of a rising tide of human revulsion against policies and actions by which our society is dehumanizing itself. Our ancestors came out of the caves. We do not wish to go back in!" 74

The seven students who protested in 1961 had, based on precedent and warning, the expectation that there would be disciplinary and legal consequences for their actions. ${ }^{75}$ Two days before the exercise, Drew Vice President John Pepin sought to reinforce those expectations with a one page memorandum that provided explicit instructions for the drill and included direct excerpts from New Jersey statutes describing the legal consequences if those instructions were not followed. ${ }^{76}$ The problem for Pepin and other university administrators was that they could do little to dissuade the most committed members of ARROW by virtue of the fact that they intended to be arrested. When the sirens finally sounded around 4:00 pm on April 28, seven students remained out in front of the Student Union, as their sheltering peers "studied the event with a variety of emotions," waiting to see the outcome of the disobedience. If any protesters or onlookers were anticipating immediate arrests, the drill concluded with disappointment. Dr. Robert Bull, a CD official at the university, told the students after the drill had concluded that they should expect their names be submitted to Madison's CD Director, Robert Deasey, who in turn would provide them to state civil defense authorities. ${ }^{77}$ It is unknown when charges were filed or the students were taken into custody. As of May 1, the Drew Acorn reported the names of those who participated in the "long-anticipated, carefully planned" protest, but no arrests had yet been made. ${ }^{78}$

\footnotetext{
74 Theodore Olson, "Resistance to CD Defended by Olson," Drew Acorn, April 24, 1961.

${ }^{75}$ Author interview with Robert A. Goff. “Oxnam Issues Statement of CD Policy,” Drew Acorn, April 17, 1961.

${ }^{76}$ John L. Pepin, memorandum to Drew University, April 26, 1961, Drew University Archives 1:2:10.

77 “Seven People Protest Civil Defense Alert," Drew Acorn, May 1, 1961. "Seven Sit Out During C.D. Alert," Madison Eagle, May 4, 1961.

78 "Seven People Protest Civil Defense Alert." With the end of the academic year at hand, this article was a coda to the student press coverage of the civil defense controversy.
} 
Local press coverage of the event was remarkably tempered from that of a year prior. The Madison Eagle devoted only one short column to the protest on May 4 which offered very evenhanded reporting of the facts, and only two additional articles were subsequently published. ${ }^{79}$ The paper reported on May 18 about an "apparent delay" in the trial of the seven students. Two of the protesters had pleaded guilty during their initial court appearance, and the remaining defendants had requested a one-week delay, which Howe granted. Seven days later, he ordered another extension when CD director Robert Deasey notified the court that "the complainant desires more time to review the case." ${ }^{80}$ It could be speculated that Deasey's request stemmed from deliberation about whether to proceed with the case, given that none of the protesters were repeat offenders, and that they had expressed intent to appeal any guilty verdict in a legal challenge to state CD statutes. Deasey considered requesting another delay the next week, but decided against it as the university's summer vacation was about to begin. ${ }^{81}$ Judge Howe also instituted a different approach to the 1961 proceedings, indicating that the court would ban student demonstrators and only be open to those officials directly involved with the case. ${ }^{82}$ The trial of the five remaining defendants concluded serenely, therefore, on Thursday, May 18. At the behest of CD director Robert Deasey testimony was given by Dr. Robert Bull and a state trooper. The defense offered up a letter from the New York Annual Conference of the Methodist Church:

In accordance with our historic tradition in the support of individuals in the free expression their conscience... Be It Resolved that we give moral and prayerful suport [sic] to the young people at Drew University, who by

\footnotetext{
79 “Seven Sit Out During CD Alert," Madison Eagle, May 4, 1961.

80 "Delay is Apparent in Drew CD Trial," Madison Eagle, May 18, 1961. It should be noted that local coverage of the trial was delayed by a full week because the Madison Eagle was published weekly on Thursday mornings, and municipal court was in session on Thursday nights.

81 “Drew 'Sit-Outs' Fined by Judge," Madison Eagle, May 25, 1961.

82 "Delay is Apparent in Drew C.D. Trial," Madison Eagle, May 18, 1961.
} 
conscience, were led to refuse to obey the State Law in the recent civil defense exercise. ${ }^{83}$

Whatever moral authority may have been bestowed upon the students with this letter, Judge Howe was not to be swayed. While Nancy Frith and Janet Sykes received fines of $\$ 10$ court costs for pleading guilty, the other five individuals were fined $\$ 25$ a piece, plus $\$ 10$ court costs. ${ }^{84}$ The judge issued a stern warning before court was adjourned: jail sentences would be issued to anyone who protested the next CD drill, regardless of whether or not it was a first offense ${ }^{85}$ In a report reflecting upon the events of the preceding weeks, Dean Allen Weatherby expressed pleasure at how everything had unfolded, from the "Judge's deportment," to the behavior of the Drew students. ${ }^{86}$ One would not be reaching too far in surmising that everyone was pleased with how the legal proceedings were conducted and reported compared with the outrage and indignation of a year prior. Another "Roman Circus" had been avoided.

Lois Congdon and Neal Mosher were the only two protesters who opted to move forward with an appeal to the New Jersey State Superior court. State v. Congdon (76 N.J. Super. 493) was argued on September 10, 1962 before a three-judge panel of the appellate branch. Judge Freund issued the court's opinion on October 16. After laying out the facts of the case (including the planning and preparation undertaken by ARROW) and reviewing relevant statutes, Freund dissected the arguments made by the appellants' attorney, Mr. Emerson L. Darnell of Moorestown, NJ. Darnell sought to overturn Congdon's and Mosher's convictions on the grounds that, under state law, $\mathrm{CD}$ personnel were not empowered to compel the public to take shelter in the course of an air raid drill. The appellant also argued that the directives instructing

\footnotetext{
${ }^{83}$ Letter from C. Wesley Christman, Jr. to Raymond Harrison, Jr., May 25, 1961, located in Drew University Archives, 1:2:10. Christman was the Methodist Church Secretary of the New York Annual Conference; Harrison was a faculty member at Drew.

${ }^{84}$ According to letter from Neal Mosher to the author, a Quaker congregation in nearby Scotch Plains, NJ took interest in the students' case and paid their court fines. Neal Mosher, letter to the author, April, 2019.

85 "Drew 'Sit-Outs' Fined by Judge."

${ }^{86}$ Dr. Allen Weatherby, Report of May 18, 1961, Drew University Archives, 1:2:10.
} 
the public to take shelter were not properly issued. Finally, Emerson presented three challenges: First, that the term "take cover" in the statute was unconstitutionally vague; second, that "the present requirement of public participation in an air raid drill constitutes an invalid delegation of legislative power." Finally, the appellant attorney argued that his clients' First Amendment rights to freedom of speech and freedom of religion had been infringed by the state. ${ }^{87}$

Judge Freund rebuffed all of the appellants' arguments in his decision. As to the argument that the free speech rights of the protesters had been violated, it appears that the actions of ARROW undercut this claim. Freund noted that "the defendants freely circulated pamphlets" (the two bulletins issued by the student organization), "they held an open-air meeting" prior to the drill, and "freely disseminated their views" in the press. If one were to consider the appellants' right to picket under the First Amendment, existing case law provided that "picketing may be legislatively regulated as to time, place, and purpose." The same can be said for the claim that freedom of religion was curtailed, as Freund used ARROW's own language against the students. Although one of the two flyers distributed by the group made mention of "Christian concern" and "the leadings of conscience," Freund found that "the principal motivation clearly was not religious" because the students had cited moral and philosophical beliefs much more commonly than religious ones. Even if they had been, case law dictated that the right of religious belief was not absolute and must be at times "compromised" with the necessities of "communal life." 88 One recurring theme of Freund's decision was the significance of the state's police power, which his decision cited eight times. His penultimate paragraph encapsulated his application this doctrine to the case:

A civil defense drill is much more than an enforced ritual. It is potentially a matter of life and death. As we have already pointed out, the basis of the

\footnotetext{
87 “State v. Congdon, 76 N.J. Super. 493 (1962)," Justia. Cited content contained on pages 503 - 508.
}

${ }^{88}$ State v. Congdon. Cited content contained on pages 508 - 509 of the ruling. 
State's police power is the protection of its citizens. This protection must be granted irrespective of the fact that certain individuals may not wish to be saved or protected... The State may...take steps to reduce the exposure of the citizens to... atomic bomb radiation. ${ }^{89}$

The student activists of Drew University and all they represented lost in a court of law in 1960, 1961, and 1962. From a legal perspective, such a record indicates little chance of future success. In democracy, and in the court of public opinion, that often matters very little.

Students at Drew University grappled with life in the nascent Atomic Age long before Operation Alert or ARROW came to be. In the months following news of the two atomic bombings that secured Japan's surrender in World War II, the Drew Acorn featured numerous articles and editorials expressing the new "nuclear culture," and deliberation amongst the student body for how to cope with this perilous modern era. In "Year Two of the Atom," one such passage expressed the arrival of a carpe diem moment: "Only thoughtful men and women, working together with new ideas and still fresher ideals, can save the civilization of their creation. Here comes another term. Here comes opportunity." 90 More than one decade and many terms after these ruminations appeared in the Acorn, thirteen students seized that opportunity, living up to the spirit of Drew in their ideas, ideals, words, and actions.

This case study of protest offers a new interpretation of the shift in American public consciousness regarding the value and necessity of civil defense. During OPAL's early years, most of the resistance to the air raid drills was done by veteran activists of a wholeheartedly pacifist persuasion. These protests were initially isolated to large cities, and were met by relative indifference on the part of the public. This changed by 1960, when a growing number of neophyte protesters were motivated to partake in the resistance, increasing the movement's numbers and geographic distribution. If civil defense planning was developed by the government

\footnotetext{
${ }^{89}$ Ibid. Cited content contained on pages $511-512$ of the ruling.

${ }^{90}$ Ibid.
} 
as a "blueprint for social control..." as Andrew D. Grossman suggests, it was becoming increasingly clear by 1960 that activists were successfully undermining that goal. ${ }^{91}$ The general public began to more openly question the manner and effectiveness of nuclear-strike preparation. In the words of Dee Garrison, "The fantasy was exposed. The people revolted. And social conflict threatened elite controls. $" 92$ In resisting Operation Alert, the students of Drew University and their fellow activists were the ones working to expose the fantasy.

These two fifteen-minute incidences of civil disobedience are just a small piece of the story. The ripple effects of the protests emanated outward from the lawn in front of the Student Union, temporarily enveloping the campus and the town of Madison. As has been the case in many instances throughout history, the punitive response to the protest became a bigger story than the act of resistance itself. Had it not been for the decision of Ralph Smith or Charles Nelson to press charges, had it not been for an offensive opinion editorial in the Madison Eagle, had it not been for Judge John Howe's oppositional demeanor, the 1960 protest may have been lost to history. It certainly would not have resulted in a frenzy of public deliberation that lasted for nearly two months. In making examples of the six protesters, law enforcement and the press awakened the public in opposition to perceived mistreatment. Community member John P. Snyder commented on this at the time of the second incident, writing: "I hope that the court and the press will be less vindictive than they were last year, if these students are arrested." $" 93$ The proactive steps taken by the University administration in 1961 to avoid a repeat of the "circus" were self-defeating, as they further emboldened the student activists to take a stand (not just in the form of civil disobedience, but also to openly challenge the authority of administrators). While the public relations headaches of a year before were largely avoided, that was due more to

\footnotetext{
${ }^{91}$ Grossman, Neither Dead nor Red, 37.

${ }^{92}$ Garrison, Bracing for Armageddon, 192.

${ }^{93}$ John P. Snyder, Letter to the Editor, Madison Eagle, April 27, 1961.
} 
media restraint and the predictability of how things would unfold, given the precedent that existed.

The other considerable change demonstrated by this case study is the progression of activist organization and intentions in less than a year's time. The creation of ARROW and the group's subsequent actions to plan and execute a protest in opposition to OPAL ' 61 seem demonstrative of how a spontaneous, disorganized gathering evolved into a formalized, purposeful campaign. Theodore Olson and his five comrades had only the desire to take a public stand of resistance according to their own convictions. The activists of ARROW, while also acting "for conscience' sake," developed a plan to achieve their longtime goal of producing a legal challenge to civil defense drills. Although they ultimately failed in a court of law, the evolution from one year to the next seems remarkable given how small and isolated the protests actually were. This progression cannot be credited to the students alone, however. Although ARROW remained an unaffiliated ad hoc organization, the students were clearly inspired and influenced by the work of SANE, the Student Peace Union, plus other prominent organizations and activists.

In defying the Operation Alert drills, Drew's students were at the periphery, not the epicenter, of the movement to resist civil defense. The epicenter was occupied by the veteran activists in New York City such as Dorothy Day and organizations like the War Resisters League. For a few months in 1960 and 1961, however, the student cohorts were one of many focal points in a debate that was unfolding around the country. Their acts of resistance linked them with those at the epicenter through people such as attorney-activist Esther Frankel and WRL campaigner David McReynolds. Their actions also pitted them against campus administration, local officials, the press, and the law. The historical record, however, indicates 
none of that mattered very much to the student activists. What did matter was the compass of one's personal convictions amidst a society conforming to the possibility of nuclear immolation. Regardless of the success or size of their campaign, the student protesters followed their conscience to oppose this conformity, and in so doing, challenged many others to reckon with that troubling reality.

Daniel J. Willever is a 2012 graduate of Gettysburg College and recently earned a master's degree in History and Culture from Drew University. He is a Social Studies teacher at Ramsey High School in Bergen County. He was recognized as New Jersey's 2019 recipient of the Milken Educator Award, a national prize for excellence in teaching. 